\title{
散乱波を考慮した室内音場のインパルス応答予測計算法 NUMERICAL SIMULATION OF AN IMPULSE RESPONSE FOR ROOM ACOUSTIC DESIGN
}

\author{
坪井政 義*
}

Masayoshi TSUBOI

\begin{abstract}
The purpose of this paper is to study and to propose an efficient method for calculating a long-time impulse response ranging over audio frequencies in a room. This method, based on the numerical integration of Kirchhoff's integral equation, carries out integration with technique both for tracing the potentials of the identical phase elements like the Fresnel zone of a propagating wave-front and for dividing into a spherical wave part and a dispersal wave part.

The effectiveness of this method is confirmed by comparison between calculated value and measured.
\end{abstract}

Keyword : Phase Element Integration Method, Kirchhoff's boundary condition, Fresnel zone 波面積分法、キルヒホッフの境界条件、フレネル輪帯

\section{1.はじめに}

最近のコンピュータのハード・ソフト両面での急速な発展により、 ヴァーチャル・リアリティ(VR) 技術の応用分野の一つとして、計画 段階において実際に設計した空間の音場を体験して評価できるように、 コンピュータシミュレーションによる予剆計算と予測音場の可視化や可 聴化手法の研究が進められている。基本計画段階で室内形状や内菨材 等の音響特性が異なった様々な音響設計案に対して、入力データを変え るだけで迅速に音場を予則して比較検討ができるコンピュータシミュ レーションが、有効な設計支援手法の一つになりつつある。

室内音響設計支援を目的として、筆者らも音場の予測計算法及び音場 評価支援用に音場の視聴覚化技術の研究を進め、これらを統合した室内 音響シミュレーションシステム1を開発してきた。

ここで、根幹となる音場の予測精度についてみると、一般に広く使わ れている幾何音響をべースにした虚像法や音線法では、回折等の音の波 動性が無視されていることにより、波動性の影響が無視できない低音域 では、特に誤差が大きくなってしまう。これらの計算手法は室内の基本 形状における音響障害の有無のチェックや音響反射板の設置角度等の基 礎的項目で, 中高音域に限定した検討では利用できるものの、低音域を 含む可聴帯域全体が対象となる音場評価には適さない。

コンピュータシミュレーションの迅速性等の利点を生かして、ニース
に合わせた室空間の音響設計に効果的に用いるためには、様々な設計空 間の音場を比較検討できる予剆精度の高い音場計算法が望まれている。 現在までに、波動方程式と等価なキルヒホッフの積分方程式をもとに して可能な限り正確に音場を計算する手法として、以下のものが発表さ れている。

音場の境界の速度ポテンシャル及び法線微分を末知関数として、寺井. 河井りによって樻分方程式が定式化され簃密な解法が得られている。現 在は、それらの境界面上の未知関数は数値的に解かなければならない。 実際のオーディリアムの音場計算をするためには、例えば可聴帯域の 上限とされる周波数 $20 \mathrm{kHz}$ までを計算対象とすると、サンプリング定 理より、 $20 \mathrm{kHz}$ の半波長 $(=8.5 \mathrm{~mm})$ 以下のサイズで要素分割しなければ 成らず、膨大な要素数になってしまう。したがって、現在のコンピュー 夕の演算処理能力では、計算できる要素数が限られてしまい、実際の オーディトリアムの音場計算に適用して中高音域までにわたる可聴帯域 全体を計算することは難しい。

オーディトリアムの音場予測のために、桜井 ${ }^{3)}$ はキルヒホッフの境界 条件から導いた線積分公式を用いて、㓮平板からの反射音の重ね合わせ としてレスポンスを扱い、高い周波数までの初期反射音の計算が可能な ことを示している。しかしながら、高次の反射計算になるにしたがって 急速に增える虚音源に比例して演算時間が増加するために、実際のオ一 
デトリアムの音場計算では反射次㪉の増加と共に計算が困難となる。 音瑤設計支摇への実用化手法として、関口、他 ঐは音線追跡の手法 をべースにした有限音線積分法を用いて、初期インパルス応答の計算を 行なっている。しかし、常に球面波を仮定し波面を微小要菜に分割して 畿何学的音線により音の多次反射伝搬を追跡しているために、反射面の 寸法より波長が大きいために回折伝搬の寄与が大きくなる低中音域や、 球面波の仮定が成立しにくくなる反射次数が多い反射音では、原理的に 誤差が大きくなってしまう。また、残響成分までを含む長時間にわたる インパルス応答（以後、長時間インパルス応答と称する）の計算を行お うとすると、発音からの経過時間に伴い離れていく音線間隔を、計算対 象の上限周波数の半波長以下に保つように、追跡音線本数を追跡時間の 二乗に比例して増加させなくてはならず、演算時間が激增してしまう。 残響成分は、ホールの中央とバルコニー下や後壁などの吸音壁近傍と では明らかに差が出るが、これらの計算手法では、音場の視覚化や可聴 化による音場評価に用いるための基盤データとなる可聴带域の全周波数 绩報を含み、かつ残響部分までの長時間のインパルス答を予測計算す るには、膨大な要䒺数と演算時間が必要であり、実用上困難である。

そこで、これらの研究を踏まえつつ、音響設計の支援を目的とした可 視化や可聴化による音場評価に用いるための基盤データとなる長時間イ ンパルス応答の実用的な予則計算手法を検討することにした。

まず初めに、ある受音点に到達した長時間インパルス応答波形を成分 別に見ると、比皎的音圧振幅が大きく幾何学的に位相追跡が容易に可能 な直接音、一次回折等の低次回折音、鏡面反射音のグループ (以後は幾 何学波成分と称する)と。これ以外の位相追跡が比較的複雑で困難とな る多次の回折音や散乱音などから成るグループ(以後は散乱波成分と称 する）とに、大きく分けることができる。

\section{インパルス成答 $\Rightarrow$ 幾何学波成分 + 散舌波成分}

次に、長時間インパルス応答波形を時間で区切って、直接音や初期反 射音成分からなる初期応答と、それ以降の残響に相当する中後期応答と の二つに分けてみる。発音から一次反射までは球面波からの幾何学波成

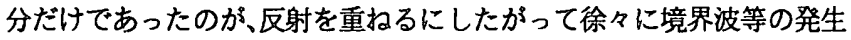
により散乱波成分が多くなることから、初期応答では幾何学波成分が多 く、中後期応答では散乱波成分が多く占め、後期応答の残響部分ではほ とんどが散乱波成分になってしまう。これらに着目し、幾何学波成分を 精度良く計算できる計算モデルと、散乱波成分を効率的に精度良く計算 できる計算モデルとを開発し、これら二つを合成することで、飛躍的な 演算時間の増加なしに長時間インパルス応答の計算を可能とした。

幾何学波成分でのm次の多次反射音の計算は、㳄反射面への入射 音の特性が解机は、この面への一次反射音と同様に計算できる。この 入射音の特性は、m-1次反射して伝搬する際の境界波で決定され、この 境界波がフレネル翰帯要案の伝搬欠損により生じることに着目して、入 射音特性を翰带要䒺を伝搬追跡して求めている。3次元空間にて球面波 面の第 $\mathrm{j} フ レ ネ ル$ 輪帯エリアをm-1次反射まで伝搬追跡すると、その軌 跡は田-1次虚音源と受音点を通る線分を含む断面では桂円形状となり、 この線分と垂直な断面では正円形状となる円简型棈円曲面を描く。この 翰帯要意は、音源や受音点の近くでは小さくて細かく、遠く離れると大 きくなるため、この要絮で境界面を離散化することで、入カデータとし て亨前に細かく要絮分割するものに比へて、応答への寄与の大きさを反 映した計算奻率のよいものとなる。また、従来から音響設計支援に利用 してきた幾何学手法での音響計算用の入力デー夕構造を踏啫できる。以 下に、これらの計算モデルと、実測値との比較を通して有効性を示す。
2. 計算モデルについて

\section{1.閉空間の音場を示す基磽式}

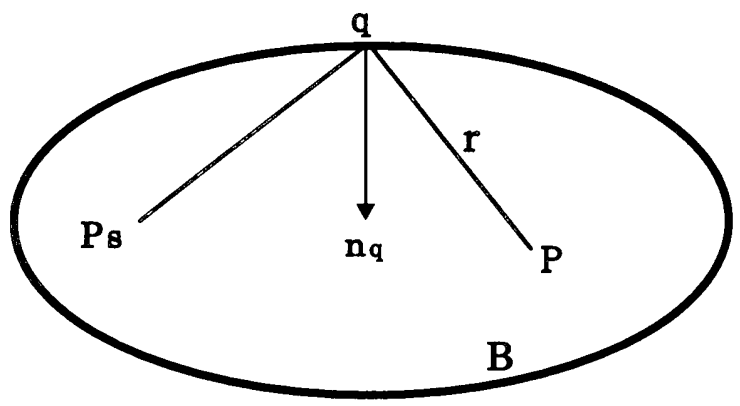

図 1 閉空間の音場

図 1 に示すなだらかな閉曲面 $\mathrm{B} に$ 囲まれた閉空間の内部において、無 指向性点音源P sで角速度 $\omega$ で駆動する定常音源がある場合に、受音点 $\mathrm{P}$ での速度ポテンシャルゆは、Helmholtz-Kirchhof f $の$ 積分方程式に より、次の式で表現される。ただし、時間因子を表す $e^{- \text {はax }}$ は省略して いる。

$$
\begin{aligned}
& \Phi(P, \omega)=\Phi_{D}(p, \omega)+1 /(4 \pi) \cdot \int_{\mathrm{B}}\left\{\Phi(q, \omega) \partial\left(e^{-u r} / r\right) / \partial n_{q}\right. \\
& \left.-\partial \Phi(q, \omega) / \partial n_{q} \cdot e^{-t k r} / r\right\} d S_{q} \\
& \text { ただし、 } \Phi_{D} \text { : 音源からの直接音 } \\
& n_{q}: \mathrm{B} \text { 上の点 } \mathrm{q} \text { での内向き法線 } \\
& r: \text { 受音点 } \mathrm{P} \text { から面上 } \mathrm{q} \text { までの距離 } \\
& k:(=\omega / c) \text { は波数、 } c \text { : 音速 } \\
& \text { ८: } \iota^{2}=-1 \text { (虚数符号) }
\end{aligned}
$$

過渡音場に対しては。(1) 式を逆フーリエ変換することにより、 Kirchhoff の積分方程式として、次式が得られる。

$\phi(p, t)=\phi_{D}(p, t)$

$$
\begin{array}{ccc}
+1 /(4 \pi) \cdot \int_{B}\left\{\phi(q, t-r / c) \cdot \partial(1 / r) / \partial n_{q}-\partial \phi(q, t-r / c) / \partial\right. & n_{q} \cdot 1 / r \\
-\partial \phi(q, t-r / c) / \partial t \cdot 1 /(c r) \cdot \partial & \left.r / \partial n_{q}\right\} d S_{q} & \cdots \cdot(2) \\
\phi_{D}: & \text { 音源からの直接音 } \\
& \left(\Phi_{D} \text { の逆フーリエ変換 }\right)
\end{array}
$$

(1) 式の境界面上の $\Phi(q, \omega)$ 及び $\Phi(q, \omega) / n_{q}$ 、または(2) 式 の $\phi(q,-r / c) 、 \partial \phi(q,-r / c) / \partial n_{q}$ 及び $\partial \phi(q, t-r / c) / \partial t$ の 知関数が求められれば計算できる。(1) 式の直接音 $\Phi_{0}$ 及び $\phi_{D}$ は、点音 源： $\Phi(s, \omega)=U(s) ， \varnothing(s, t)=u(s)$ とすると、球面波放射となり、 それぞれ次の式で表される。

$$
\begin{array}{r}
\Phi_{D}(P, \omega)=U(s) \cdot e^{-\imath \omega(R / c)} /(4 \pi R), \quad \phi_{D}(P, t)=u(s) /(4 \pi R) \\
\text { ただし、Rは } \mathrm{P} \mathrm{s} \cdot \mathrm{P} \text { 間の距離を表す。 }
\end{array}
$$

ここで、境界面上のポテンシャルから受音点 $\mathrm{P}$ への寄与は、境界面に 音源からの音波が入射して反射する毎に生じるので、これらの応答が有 限長と仮定して (1) 式を適用すると、過渡応答を捉えることができる5)。

まず、境界面上の点 q への直接音 $\Phi_{D}(q ， \omega)$ が空間内に再放射さ れることにより、周囲の境界からの最初の寄与 $\Phi$ ，が生じる。(1) 式よ り、受音点 $P$ への 1 次反射音 $\Phi_{1}$ は、

$$
\begin{aligned}
\Phi_{1}(p, \omega) & =1 /(4 \pi) \cdot \int_{\mathrm{B}}\left\{\Phi_{D}(q, \omega) \cdot \partial\left(e^{-t k r} / r\right) / \partial n_{q}\right. \\
& \left.-\partial \Phi_{D}(q, \omega) / \partial n_{q} \cdot e^{-t k r} / r\right\} d S_{q}
\end{aligned}
$$


次に得られた 1 次反射成分から同様にして2 次反射成分が計算される。 受音点 $\mathrm{P}$ への 2 次反射音 $\Phi_{2}$ は、

$$
\begin{aligned}
\Phi_{2}(p, \omega) & =1 /(4 \pi) \cdot \int_{\mathrm{B}}\left\{\Phi_{1}(q, \omega) \cdot \partial\left(e^{-l k r} / r\right) / \partial n_{q}\right. \\
& \left.-\partial \Phi_{1}(q, \omega) / \partial n_{q} \cdot e^{-l k r} / r\right\} d S_{q}
\end{aligned}
$$

したがってこの関係を一般化すると、m次反射成分は $(\mathrm{m}-1)$ 次反 射成分から同様に計算されることから. 受音点 $\mathrm{P} へ$ へ次反射音 $\Phi_{\mathrm{m}}$ は、

$$
\begin{aligned}
\Phi_{m}(p, \omega) & =1 /(4 \pi) \cdot \int_{\mathrm{B}}\left\{\Phi_{m-1}(q, \omega) \cdot \partial\left(e^{-l k r} / r\right) / \partial n_{q}\right. \\
& \left.-\partial \Phi_{m-1}(q, \omega) / \partial n_{q} \cdot e^{-i k r} / r\right\} d S_{q}
\end{aligned}
$$

過渡音場に対しては、(6) 式を逆フーリエ変換することにより、受音 点Pへのm次反射音 $\phi_{\text {m }}$ は、

$$
\begin{gathered}
\phi_{m}(p, t)=1 /(4 \pi) \cdot \int_{B}\left\{\phi_{m-1}(q, t-r / c) \cdot \partial(1 / r) / \partial n_{q}-\partial \phi_{m-1}(q, t-r / c) / \partial n_{q} \cdot 1 / r\right. \\
\left.-\partial \phi_{m-1}(q, t-r / c) / \partial t \cdot 1 /(c r) \cdot \partial r / \partial n_{q}\right\} d S_{q} \\
\text { ただし、 } \phi_{\mathbb{m}-1}:(\mathrm{m}-1) \text { 次反射音 }
\end{gathered}
$$

最終的に、受音点 $\mathrm{P}$ のポテンシャル ゆは直接音と全ての反射成分の 和として次式で表せる。

$\Phi(P, \omega)=\Phi_{D}(P, \omega)+\sum_{m=1}^{\infty} \Phi_{m}(P, \omega)$

過渡音場に対しては、

$\phi(P, t)=\phi_{D}(P, t)+\sum_{m=1}^{\infty} \phi_{m}(P, t)$

このように受音点での応答は、室内を構成する面要素からの音場への 寄与を音波が境界面に伝搬する毎に逐次求めて、それらを重ね合わせる ことにより、計算できることが分かった。ただし、実際の数値計算では、 音波の反射次数毎に、境界面上の離散化要素全てに対して、離散化要素 全てからの寄与を積分しなければならず、このままでは50次以上の反 射経路の計算となる長時間インパルス応答計算への適用は困難である。

そこで、計算精度を低下させずに計算の効率化を図る必要がある。

\section{2.境界面上の要素Aからの反射応答基礎式}

図 2 に示す閉空間 Bの境界面上の要素A からの反射応答を考える。

（4）式での閉空間内の音源から面上 $q$ 点への直接音 $\Phi_{D}$ は、

$\Phi_{D}(q, \omega)=U(s) \cdot e^{-\imath \omega\left(r_{0} / c\right)} /\left(2 \pi r_{0}\right)$

$\because q$ 点は面上にあり半空間受音 : $Q=2 \rightarrow 2 /\left(4 \pi r_{0}\right)$ 境界面上の要素Aからの一次反射波を、相補的な開口Aを通過する虚 音源Ps'からの回折波として、Kirchhoff の境界条件を適用すると、

$$
\begin{aligned}
\partial r / \partial n_{q} & =\cos \theta, \\
\partial\left(e^{-t k r} / r\right) / \partial n_{q} & =(-l k-1 / r) \cos \theta \cdot\left(e^{-l k r} / r\right) \\
\partial(1 / r) / \partial n_{q} & =\left(-\cos \theta / r^{2}\right)
\end{aligned}
$$

となるので、これらを(4) 式へ代入すると、Fresnel-Kirchhoff の 回折公式が得られる。これが、面要素 $\mathrm{A}$ からの一次反射波による受音 $\mathrm{P}$ への寄与となる。

$$
\begin{gathered}
\Phi_{1}(p, \omega)=1 /(4 \pi) \cdot \int_{\mathrm{A}}\left[U(s) \cdot e^{-t \omega\left(r_{0} / c\right)} /\left(2 \pi r_{0}\right) \cdot(-t k-1 / r) \cos \theta \cdot\left(e^{-\imath k r} / r\right)\right. \\
\left.-\partial\left\{U(s) \cdot e^{-\imath r_{0}} /(2 \pi r)\right\} / \partial n_{q} \cdot e^{-t k r} / r\right] d S_{q} \\
=1 /(4 \pi) \cdot \int_{\mathrm{A}}\left[\Phi_{D}(q, \omega) \cdot\left(e^{-\imath k r} / r\right)\right. \\
\left.\cdot\left\{(-\imath k-1 / r) \cos \theta-\left(-\imath k-1 / r_{0}\right) \cos \theta_{0}\right\}\right] d S_{q} \quad \cdots(11)
\end{gathered}
$$

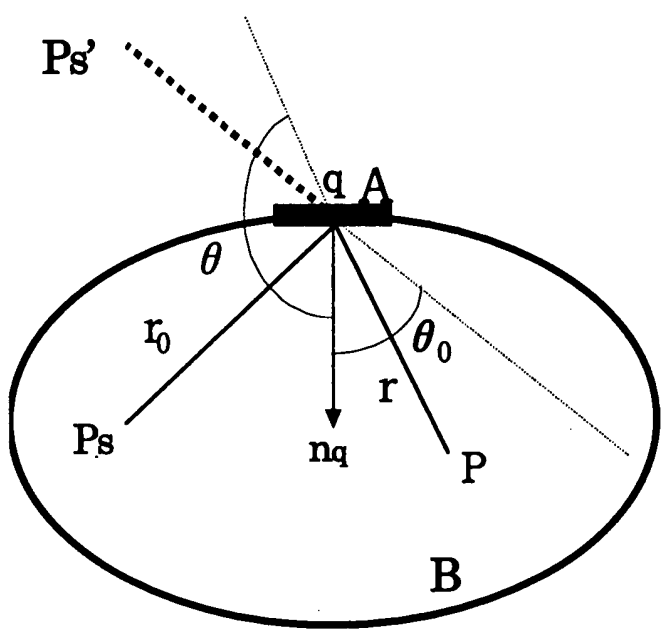

図2 境界面上要素Aからの反射音場

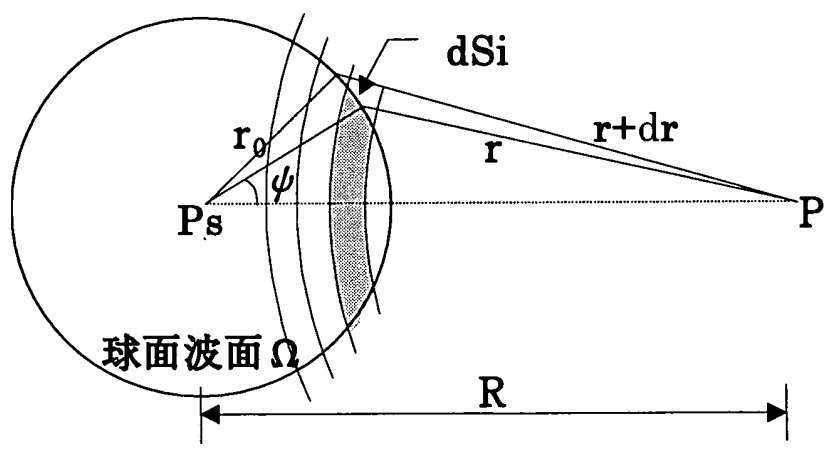

図3 球面波からの応答

$\Phi_{1}(p, \omega)=1 /(4 \pi \cdot c) \cdot \int_{A}\left[\imath \omega \cdot \Phi_{D}(q, \omega) \cdot\left(e^{-u t r} / r\right)\right.$

$\left.\cdot\left\{(-1-1 /(1 k r)) \cos \theta-\left(-1-1 /\left(k r_{0}\right)\right) \cos \theta_{0}\right\}\right] d S_{q}$

$\Phi_{1}(p, \omega)=1 /(2 \pi \cdot c) \cdot \int_{A}\left[\imath \omega \cdot \Phi_{D}(q, \omega) \cdot\left(e^{-l k r} / r\right) \cdot H_{q}(\theta, \omega)\right] d S_{q}$

・ただし、傾斜因子： $H_{q}(\theta, \omega)=1 / 2 \cdot\{(-1-1 /((\mathrm{kr})) \cos \theta$ $\left.-\left(-1-1 /\left(c k r_{\theta}\right)\right) \cos \theta_{\theta}\right)$

有限音線積分法 4)では実務使用での演算の効率化を図るために. $l /\left((k r)=-\left\langle\lambda /(2 \pi r)\right.\right.$ より、$r \gg \lambda 、 r_{0} \gg \lambda$ ג仮定して、(13) 式の 傾斜因子 $H_{q}(\theta ， \omega)$ の虑数項を無視した基礎式としているが、音響設 計を要するホールでは、境界面要素から音源や受音点 $\mathrm{P}$ までの距離が波 長に比べて十二分に大きくない場合が多く、虚数項が無視できないので 本計算では虚数項も考虑している。（13）式を逆フーリエ変換すると、 $\left.\left.\phi(P, t)=1 /(2 \pi \cdot c r) \int_{A}\{\partial \phi(q, t-r / c)) \partial t\right) * h_{q}(\theta, t)\right\} d S_{q}$ ・ただし、* $h_{q}(\theta, t)$ は傾斜因子 $H_{q}(\theta ， \omega)$ を逆フーリI 変換したものを畳み込み演算することを示す。

これより、面要素Aからの寄与は境界面上 q点での速度ポテンシャ ル $\phi$ 微分波 $\partial \phi / \partial t$ を積分合成することで得られることが分かる。

\section{3.境界面要素A $A$ 輖带要素で離散化}

ここで、効率的にサンプリグ周期 $d t_{0}$ 每のインパルス応答波形の值を求 めるために、境界面要素 $\mathrm{A}$ を $\mathrm{dr}\left(=\mathrm{c} / d t_{0}\right)$ 毎の将プリング 周波数の1/2の 周波数に対応するフレネル輪帯要素に、更に離散化する。図3に示すよ うに球面波上のある一つのフレネル輪帯 $\mathrm{i}$ の面積を $\mathrm{dS}_{\mathrm{i}}$ とすると、 


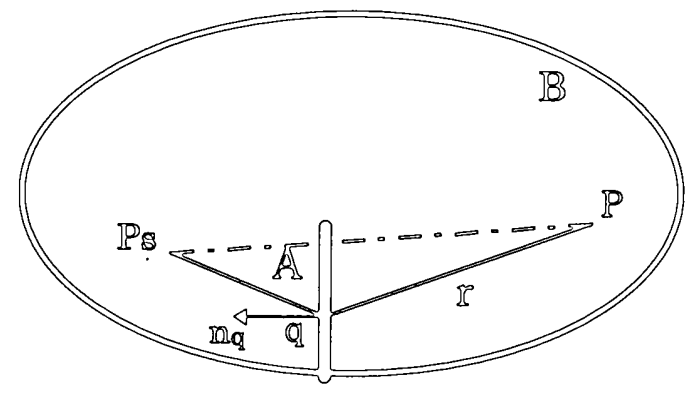

图4 遮蔽面がある回折音場

$$
\begin{aligned}
r^{2} & =r_{0}^{2}+R^{2}-2 r_{0} R \cdot \cos \phi & & \text { [三角形の関係] } \\
r d r & =r_{0} R \cdot \sin \phi \cdot d \phi & & \\
\sin \phi \cdot d \phi & =r d r /\left(r_{0} R\right) & & \\
d S_{1} & =2 \pi\left(r_{0} \cdot \sin \phi\right) \cdot r_{0} \cdot d \phi & & \text { [円周長 } \times \text { 帯幅] } \\
& =2 \pi r_{0} / R \cdot r d r & &
\end{aligned}
$$

球面波が前述の境界面要萎 $\mathrm{A}$ へ入射する場合、フレネル輪带 $\mathrm{i}$ と交 差する部分の境界面要蒵 $\mathrm{A}$ 上での面積 $\mathrm{d} S$ は、翰帯 $\mathrm{i}$ が境界面要菜 $\mathrm{A}$ 一 入射し交差する面積比率を $g(i)$ 入射角 $\theta_{0}$ とすると、 $d S=d S_{i} \cdot g(i) / \cos \theta_{0}=2 \pi r_{0} / R \cdot r d r / \cos \theta_{0} \cdot g(i)$

フレネル翰帯 $\mathrm{i}$ 要絮が境界面要案 $\mathrm{A}$ へ入射した場合の応答は (11) 式 に、これを代入し整理すると、

$d \Phi_{d s_{i}}(\omega)=1 /(2 \pi R c) \cdot\left\{\imath \omega \cdot U(s) \cdot e^{-\imath \omega \cdot R / c} \cdot e^{-\imath \omega \cdot d R / c}\right\} d r$

$$
\cdot\left[\{-1-1 /(k r)\} \cos \theta-\left\{-1-1 /\left(k k r_{0}\right)\right\} \cos \theta_{0}\right] /\left(2 \cos \theta_{0}\right) \cdot g(i)
$$

傾斜因子 $H^{\prime}(\theta, \omega)=1 / 2 \cdot\{(-1-1 /(6 k r)) \cos \theta$

$$
\left.-\left(-1-1 /\left(c k r_{0}\right)\right) \cos \theta_{0}\right\} / \cos \theta_{0} \text { とすると、 }
$$

$d \Phi_{d s_{i}}(\omega)=1 /(2 \pi) \cdot \imath \omega \cdot U(s) \cdot e^{-t \omega \cdot R / c} \cdot e^{-\imath \omega \cdot d R / c} / R \cdot H^{\prime}(\theta, \omega) \cdot d r / c \cdot g(i)$

$$
\text { ただし、 } d R=r_{0}+r-R
$$

$P$ 点到達の $t^{\prime}=t-R / c$ を時間の基準として逆フーリエ变換すると、

$d \Phi_{d s_{i}}(\omega)=2 \cdot \partial \phi\left(P, t^{\prime}-d R / c\right) / \partial t \cdot d r / c^{*} h^{\prime}(\theta, t) \cdot g(i)$

ここで $\mathrm{dr} / \mathrm{c}$ は、将プリグ周波数の周期に相当し、 $d R=(n-1) \cdot d r て ゙$ あるので. 面要蒵Aへ入射した全てのフレネル倝帯要蒵からの応答は、

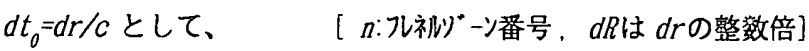

$d \phi_{d s A}(t)=2 \cdot \sum_{i=1}^{\infty} \phi\left(\left(P, t^{\prime}-i \cdot d t_{0}\right) / \partial t \cdot d t_{0} \cdot g(i)^{*} h^{\prime}(\theta, t)\right.$

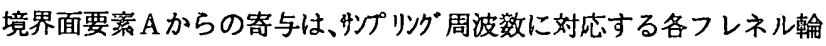
帯要素から傾斜因子を考虑した微分波を合成することで得られる。

ここでインパルス応答を求めるために計算上で発生させる音源を、 次式で示す $2 \cdot d t_{0}$ 幅の三角波とすると、

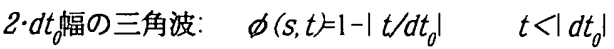

$$
\begin{aligned}
& \phi(s, t)=0.0 \quad t \geqq\left|d t_{0}\right|
\end{aligned}
$$

三角波の微分波 : $\partial \phi(s, t) / \partial t=\lim _{d t \rightarrow 0}\{\phi(s, t)-\phi(s, t-d t)\} / d t$ なので, $\partial \phi\left(s, t-d t_{0}\right) / \partial t=1.0 / d t_{0}, \quad \partial \phi(s, t) / \partial t=-1.0 / d t_{0} \quad\left[0<t \leq d t_{0}\right]$, $\partial \phi(s, t) / \partial t=0.0$

$[$ Else $] \cdots . . .(19)$ 三角波音源でのq点への入射応答波形例

球面波面

図5 境界面へ入射する球面波面を構成する2次波面伝搬追跡

サパリグ周波效の周期 $d t_{0}$ 毎の微分波は (19) 式より、隣り合ったフ レネル輪帯要意の微分波どおしの位相が相哭されるのが分かる。これと （3）式を(17)式に代入し整理すると、

$$
\begin{array}{llr}
d \phi_{d s A}(t) & =1 /(2 \pi) \cdot\left[g(1) /(R)^{*} h^{\prime}(\theta, t)\right. & {\left[t=t^{\prime} \text { の場合 }\right]} \\
d \phi_{d s A}(t)=1 /(2 \pi) \cdot\{g(i)-g(i-1)\} /(R)^{*} h^{\prime}(\theta, t) & \\
d \phi_{d s A}(t)=0.0 & {\left[\text { たたし、 } i=\left(t-t^{\prime}\right) / d t_{0},\right.} & \left.t>t^{\prime} \text { の場合 }\right] \\
& {\left[t<t^{\prime} \text { の場合 }\right]}
\end{array}
$$

隣接した輪帯要素が境界面要意へ入射し交差する面積比率 $(=g(i)$ : 以 降形状関效と称する)の差に比例して発生する単純な式で表せる。

\section{4.長時間インパルス応答鲜算汶}

一般的に音圧振幅 $\phi(t)$ と速度ポテンシャル $\phi(t)$ との関係は、 $\phi(t)$ のフーリエ変䅗村を $\Psi(\omega)$, 空気の密度 $\left(\mathrm{kg} / \mathrm{m}^{3}\right)$ を $\rho_{0}$ とすると、

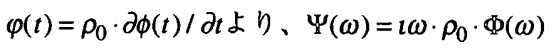

これより、 $\Phi(\omega)=\Psi(\omega) /\left(\iota \omega \rho_{0}\right)$

これを(1)式に代入すると、速度ポテンシャル ても同様な関係式が成立することが分かる。

\section{1). 啇獾音応答针算}

（3）式より、(18)式の三角波音源を音源と受音点との距離で除算するこ とで応答計算する。

\section{2). 一次反射底答针管}

一次反射面を境界面としてフレネル斛帯要絮で離散化して、(20) 式を 用いて計算する。この際の境界面への入射音特性は、境界面上の輪帯要 蒵を更に分割して、これらの分割輪帯要萦の入射波を構成する二次波面 のフレネル輪帯要意を伝搬追跡することで求めている。入射音特性を境 界面上の分割輪帯要菜からの応答に胃込み演算することで、障壁面に入 射波の一部を遮られる場合の一次反射音の応答が計算できる。

\section{3).一次回新音応答㩆筑 (図 4 参照)}

伝搬を遮蔽する面 $\mathrm{A} の$ 方向ベクトルが音源側に向いていることによ り、(20)式での面 Aからの反射音の傾斜因子が負となることから，1）の 直接音応答計算の寄与から. 面Aにより反射され遮蔽された奇与分が減 算され。結果として回折による寄与分だけが残り計算される。 

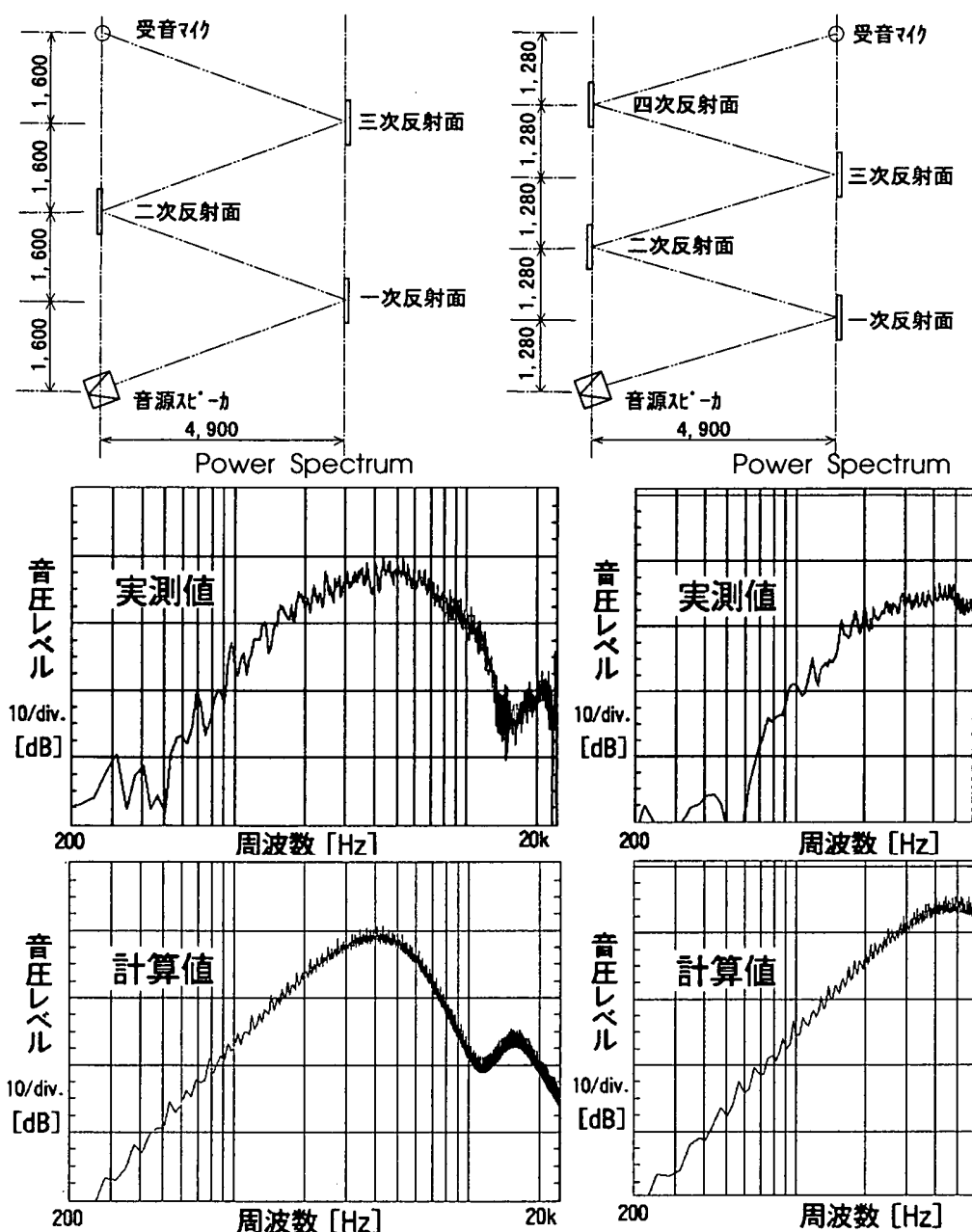

3 次反射 入射角 $18.1^{\circ}$ 伝搬経路長 $21 \mathrm{~m}$
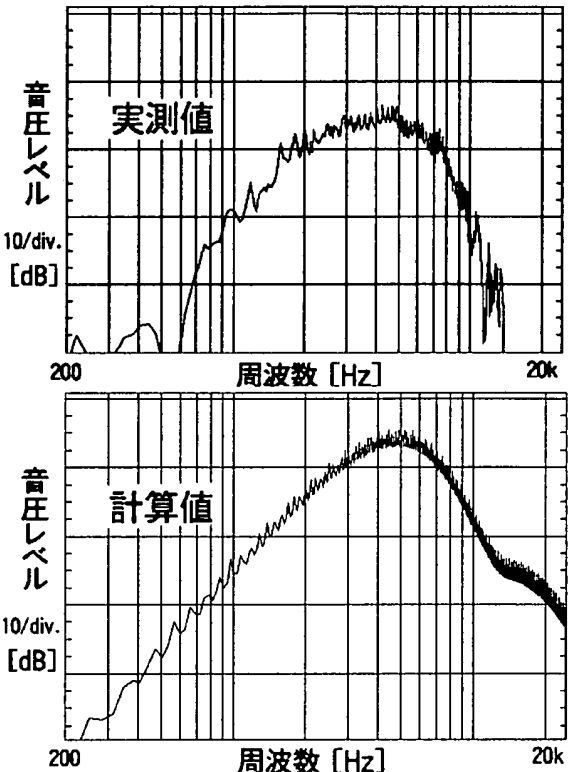

周波数 $[\mathrm{Hz}]$

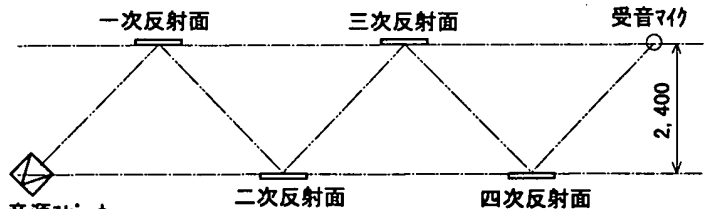

音源难 - -

二次反射面

四次反射面

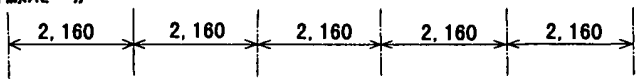

Power Spectrum

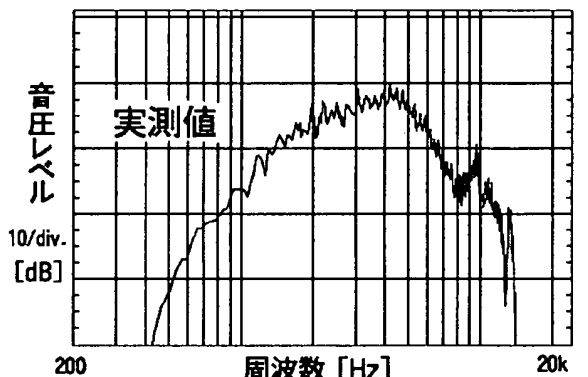

周波数 [Hz]

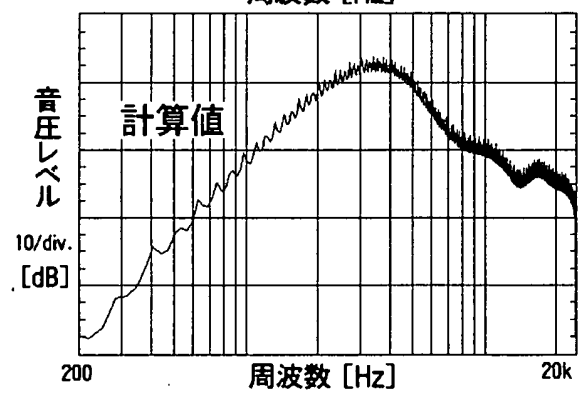

4 次反射入射角 $42.0^{\circ}$ 伝搬経路長 $16 \mathrm{~m}$ 図6 $1 \mathrm{~m}$ 正方形板の3 次. 4 次反射音の周波数特性での実測値と計算值との比較例

Power Spectrum

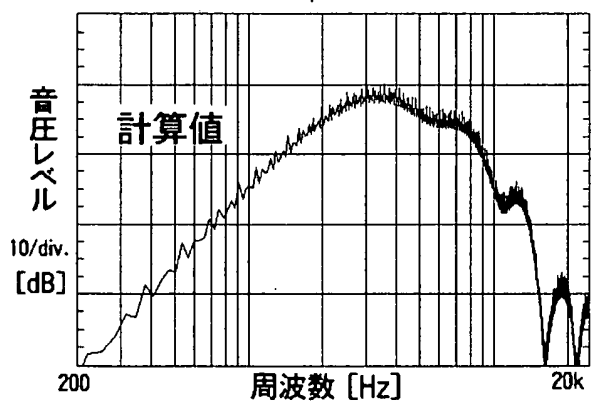

3 次反射 入射角 $18.1^{\circ}$ 伝搬経路長 $21 \mathrm{~m}$

図7 $1 \mathrm{~m}$ 正方形板の 3 次反射音の周波数特性での計算値

\section{4). 2次以上の多次反射音応答計算}

（6）（7)式に示したようにm次反射音は境界面へのm-1次反射音の積 分で計算できる。しかし、これでは原理的に多次反射の次数が一つ增 える毎に境界面要素数倍の演算を必要とするために、反射次数の増大 に伴って次第に困難となり長時間のインパルス応答計算には適さない。

そこで、境界面で田-1次反射する音の効率的な計算法を考えてみる こととする。境界面に、図5に示すような球面波の要素Aが入射する

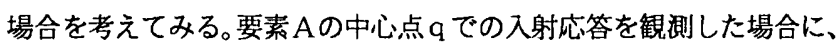
要素を構成する 2 次球面波が伝搬経路上で遮られていると、境界波が
発生して入射音の周波数特性が变わる。そこで有限寸法である要素A自 身で発生する境界波は除き、q 点に音源からの直接波到達に続いて最初 に $\Delta T$ 時間荤れて境界波が到達した場合を考えてみる。

これは、壮リソグ周波数 $f_{0} \mathrm{~Hz}$ 、周期 $\mathrm{dt}_{0} 、 j=\Delta T_{j} / d t_{0}$ とすると、要 素の q 点を中心とした円の半径 $d x\left(=c \times d t_{0}\right)$ を半波長とする周波数 $\left[=f_{0} / 2(\mathrm{~Hz})\right]$ に対芯する球面波面の第 1 から第 $(\mathrm{j}-1)$ フレネル輪帯工 リアの二次球面波面が、音源から境界面要素までの伝搬経路全てに渡り

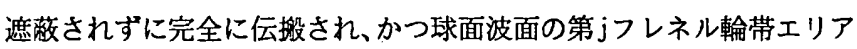
の一部または全部が伝搬途上で遮られた場合である。

これより、二次球面波面のこのフレネル輪帯エリアをm-1次反射伝搬 追跡して伝搬した形状関数 $\mathrm{g}$ (i)を求めれば、(20) 式より球面波面のm次 反射境界面への入射波が把握できることが分かる。

この入射波を、(20)式を適用した㳄反射境界面からの三角波応答に畳 み込む（周波数領域では乗算）ことにより、次反射波が計算できる。

図6に $1 \mathrm{~m}$ 正方形刏板 $(10 \mathrm{~mm}$ 厚補強有り)を用いた 3 次 $\cdot 4$ 次反射 実験で得られた反射音応答の周波数特性実則値と計算值との比較例を示 す。実測値は無響室内に反射板を設置し、12cm7ルツジ 代゙ーカからM系列 音源を発生させて、インパルス応答を測定したものに、音源スピーカの 軸方向における周波数特性の逆特性を胃込み、その応答波形の中から対 
象となる反射音応答だけを到達時刻で切り取ったものである。なお、ス ピーカ出力特性での-20dBまで許容した周波敏䉇囲は $200 \mathrm{~Hz} か 12 \mathrm{kHz}$ である。

計算值は、吹反射面全体を一次要產 $A$ として捉え、次反射面へ入 射する音を面の中央一点qでの入射音特性を翰帯要䒺の伝搬追跡により 計算し、この入射音特性が次反射面全体に入射するとして、この面で 反射するインパルス応答を合成したものである。次反射面全体を一次 離散化要蓄として、同じ特性の入射音が入射するとして近似したが、こ の条件でも $4 \mathrm{kHz}$ 以下の周波效帯域では、ピーク周波效のレベルより 20dB低下したレベルの周波效まで、よく対応しており、この計算モテ ルの有奻性が分かる。

このように、㳄反射境界面への入射波に大きく寄与するのは, m-1 次幾何反射伝搬してくる音であるので、この入射波を効率的に捉えるた めに、音源から球面波を等分割して、この分割波面要絮を音線に代表さ せて追跡する。境界面に分割波面要絮が入射する毎に交差したエリア を境界面要室として、受音点に対する応答を計算する。これにより (20) 式での入射波計算時の傾斜因子は 1.0 となり、更に単純な式となる。

この手法の有効性をみるために、50,000要糹に等分割した分割波面 要蓄を放射させて、図6にて実測値と計算値とで高音域でのディップ周 波数のずれがあった3次反射応答を対象に計算した結果を図 7 に示す。 3次反射面には17個の分割球面要䋦が入射するため、反射面が17個の 一次要菜に分割される。それぞれの一次要系毎の入射音特性が、これら の一次要索を構成する二次波面でのフレネル翰带要絮の伝搬追跡によっ て、求められている。図6における反射面を1つの要䒺として、入射音 特性を同一とした場合に比べて、反射面を分割してそれぞれの入射音特 性を考虑することで、高音域での特性が実測値に、より対応するように なっている。このように、球面波を等分割した分割波面要蓄の数が多 いほど、境界面が細かな一次要菜に分割されるために、より高音域まて 精度よく計算できるが、この分割要絮效と演算時間はほぼ比例している ので、精度を確保したい上限周波效とその演算時間を天秤にかけ、実用 的な分割数を計算対象の物件毎に決める必要がある。

ここでは、㳄反射境界面の入射波は音線経路上の面に対して倝帯要 蓄の伝搬追跡により、形状関效 $\mathrm{g}$ (i) を求め計算したか、三角波音源の 球面波として入射しなかった成分は、全て次の散乱波成分とした。

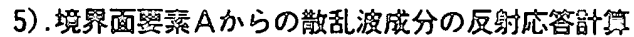

吹反射の境界面へ三角波音源の球面波として入射しなかった $\mathrm{m}-1$ 次 反射して伝搬した散乱波成分は、m-1次幾何学反射して伝搬した際に発 生した境界波の到達時刻以降に、境界面上に入射する球面波面を想定し、 その面上に速度ポテンシャルがランダムで不均一に分布し、そこから進 行方向と位相がランダムな微分波が発生していると想定した。これを 計算モデル化し、 $\{\mathrm{g}(\mathrm{i})-\mathrm{g}(\mathrm{i}-1)\} \times \mathrm{RND}(\mathrm{x})$ として、(20)式を利用してい る。ただし、RND $(\mathrm{x})$ は -1 から+1 までの乱效を発生する関效である。こ れに4)で入射しなかった（1-入射伝搬周波数特性）の重みを垂算して散 乱波成分応答を求める。なお、散乱波成分モテルの受音点に対しての寄 与をみると、進行方向が球面波の法線ベクトルに均一配置されている幾 何学波成分に比べて、散乱波成分では球面波上にポテンシャルがランダ 么配置されて進行方向と位相とがランダムなので、球面波の法線べクト ル方向への寄与はエネルギーで1／4で、かつ実効値振幅となる。

6)．吸音面の取り极い

境界面での反射係效として、特に幾何学波成分の計算では、音の入射
角度別の位相と振幅情報を含んだ複䒺音響インピーダンスが理想だが、 実際のホールでの初期反射音を発生させる面は、一般的に吸音の少ない 反射性のコンクリートやボードであるために、入射音の方向が異なって もほとんど变わらないために、残響室法吸音率を用いても誤差が少ない と思われる。また。この計算手法での分割波面要䒺がある程度の大き さをむつために、局所作用(Locally Reactive)の仮定が成り立たない ので、音響インピーダンスを吸音特性として利用しても誤差が生じる。

これに対して、残響室法吸音率は分割球面波要意によってある大きさ の一次要素に離散化された境界面の吸音特性として、あらゅる方向から の入射音に対して適用できる。さらに、初期応答に続く中後期応答で は散乱波成分が多くなるために、あら油る方向からの入射音に対する吸 音特性である残罌室法吸音率が、散乱波成分の吸音特性に合っている。

そこで、残響室吸音率データからスプライン補完して位相ずれのない 直線位相モデルと仮定した伝達関效を推定して、この值を波面要絮が境 界面で反射する毎に反射係效として用いている。

ここでは一般に公表されている 1 oct. 毎の残響室法吸音率データか ら、内装材の伝達関數を、スプライン補完で $48 \mathrm{kHz}$ サンプリングの位

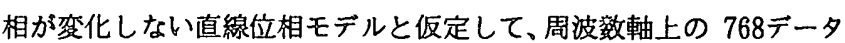
(31. 25Hzピ ッキ) 、及ぴ時間軸上の 1536 データ(32msec. 幅) のイン パルス応答として近似している。

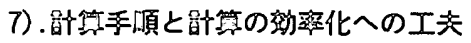

長時間インパルス応答計算の流れをまとめると、

St e p 1．直接音、一次回折, 一·二次反射の初期応答は、虚像法 の境界面組み合わせで、(3)，(4)，(5)式の逐次境界面上の輪帯要蒵の総 当たりで、(20)式を適用して、入射音特性を考虑して応答計算する。

S t e p 2. 三次反射以降の応答は、音源から発生する球面波面を等 立体角の球面波要意に分割して、音線法の要領で追跡、境界面に入射す る毎に球面波要絮を境界面分割要案と見なし、入射波を構成する二次波 面上の翰带要絮の伝搬追跡によって境界波の発生を検知し、裁何学波成 分である境界面への入射波伝搬特性を計算する。

S t e p 3. 境界面上での分割球面波要素内は幾何学波成分の境界面 入射波伝搬特性は一様であるとして、この境界面の球面波要絮エリアを

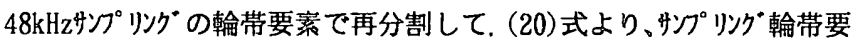
意からの微分波を積分してインパルス応答を計算し、入射波の伝搬周波 效特性の重みを掛けて合成する。

S t e p 4. 境界波発生時刻以降に仮想した球面波面上に散乱波成分 計算モデルを分布させ、(1-伝搬周波效特性)の重みを掛けて合成する。

S t e p 5. 詳細は別の機会に変るとして、可聴化の準備のため. 受 音点から見た境界面要意の方向で分けた方向別のインパルス応答に各方 向毎の頭部伝達関数(142方向のデータベース）を畳み込み、両耳のインパ ルス応答を計算する。

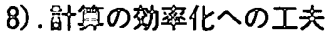

球面波として境界面へ入射する音を的確に捉えるために、点音源から 発生した球面波面を等立体角で分割した波面要絮を境界面の一次離散化 要蒵とする。その波面要寀内のポテンシャルは反射面や空気吸収で吸音 される以外は一定として、音線に伝搬経路を代表させ幾何学反射させて 追跡する。反射伝搬追跡は、一次詴散化した分割波面要甞はサッカー ボールの構成面のように6角形を基本として(一部は 5 角形の要素)い るので、波面要甞エリアの頂点が室内を構成する境界面に対して一つも 入射しなかった場合、または球面波成分伝搬率が 0.0 となった場合は、 


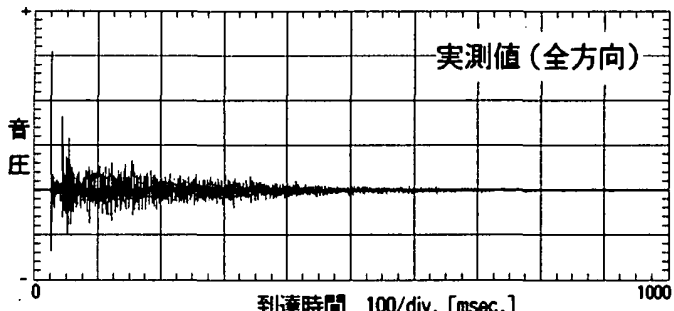

到趭時成 100/div. [ $\mathrm{msec}$.

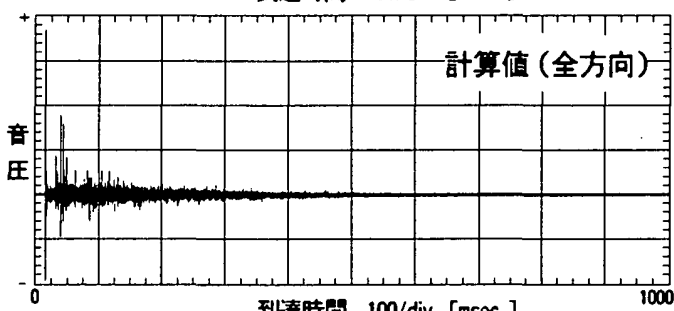

$1 \mathrm{~F}$ 中央席

$D=0.54$

$\mathrm{Ts}=0.09 \mathrm{msec}$.

$\mathrm{RT}=1.52 \mathrm{sec}$.

$D=0.51$

$T \mathrm{~s}=0.09 \mathrm{msec}$

$\mathrm{RT}=1.50 \mathrm{sec}$

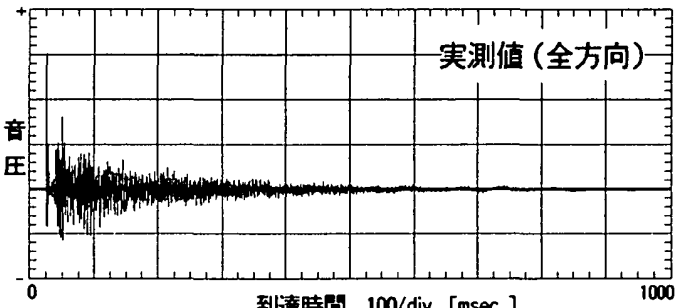
到湭時成 100/div. [msec.]

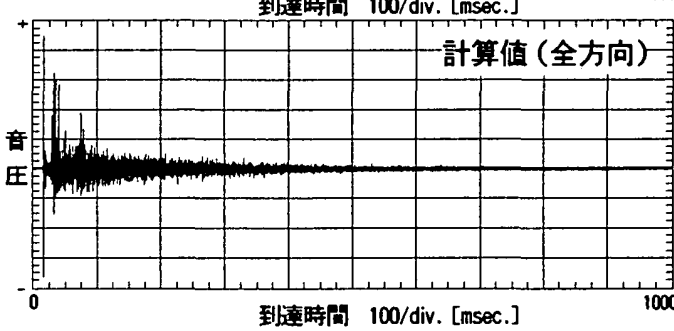

$2 \mathrm{~F}$ ベル二中央席

$\mathrm{D}=0.41$

$\mathrm{Ts}=0.10 \mathrm{msec}$. $\mathrm{RT}=1.46 \mathrm{sec}$

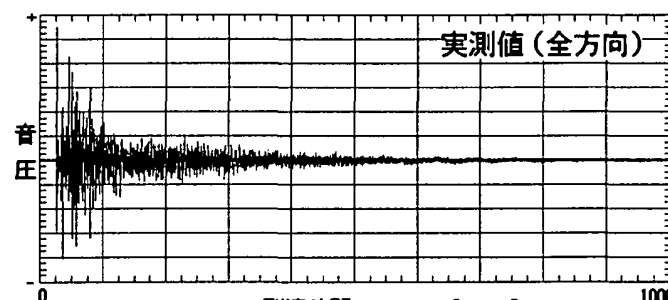

$D=0.58$

$T \mathrm{~s}=0.07 \mathrm{msec}$.

$\mathrm{RT}=1.40 \mathrm{sec}$

到達時问 100/div. [msec.]

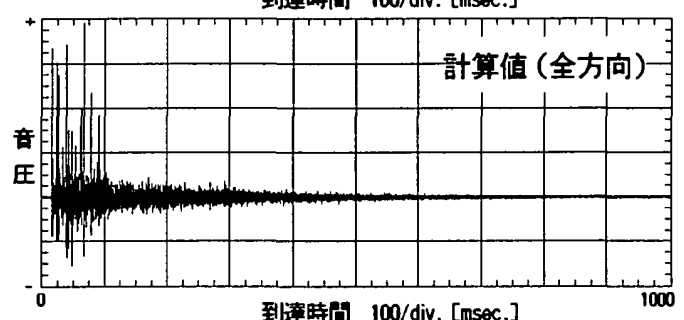

Fペルבニー下 斗仆席

$D=0.59$

$\mathrm{Ts}=0.07 \mathrm{msec}$. $\mathrm{RT}=1.45 \mathrm{sec}$

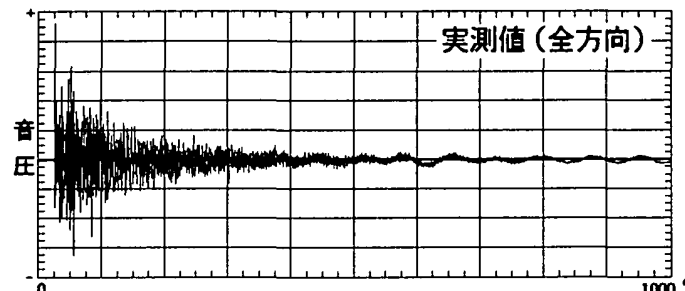

$D=0.40$ $\mathrm{Ts}=0.10 \mathrm{msec}$. $\mathrm{RT}=1.50 \mathrm{sec}$

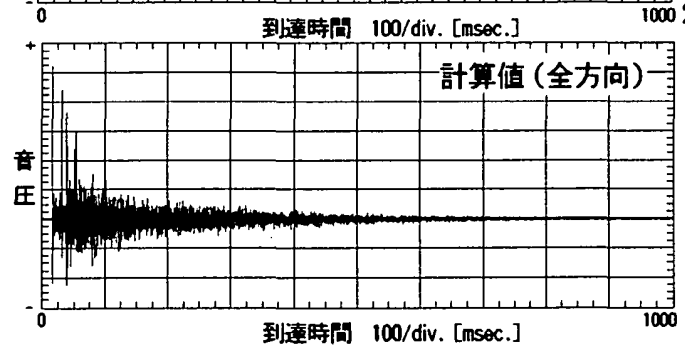
$2 \mathrm{~F} ヘ * ル ב=-\frac{n}{6}$ 斗仆席

$D=0.37$ $\mathrm{Ts}=0.10 \mathrm{msec}$. $\mathrm{RT}=1.53 \mathrm{sec}$.

図8 多目的ホールのインパルス応答での実測値と計算値との比較例

それ以降の波面要素エリアは全て散乱波成分とし反射伝搬は入射方向を 考虑したランバートの方向余呅則の確率に從って波面要素をランダム反 射させて追跡した。

計算は、時間の掛かる時系列データの畳み込み演算を避け、これと等 価な周波数軸上のかけ算で行うようにした。

また、音場評価では初期反射応答と中後期の炕答とが同程度の重みな のでここれらを予測計算するための演算時間も同じ程度にして、演算時 間配分を初期反射応答の予測精度向上に割くために工夫している。本報 では初期応答を $300 \mathrm{msec}$. までとみなして、等立体角で分割した分割波 面要素である境界面の一次離散化要素の数を音の発生から $300 \mathrm{msec}$. 経 過毎に半減させ、長時間インパルス応答計算の演算時間の増大を、 $300 \mathrm{msec}$. までの初期反射応答計算の 2 倍程度に抑えている。

\section{9）.ホール実測値との比較による計算法の検証}

図8に 1.300 人収容の多目的ホールでの長時間インパルス忘答波形 の12面体スピーカ音源での実測値と分割球面波要素数 10,000 での計算 值との比較例を示す。波形形状と音場評価の物理指標値が良く対応して おり、この計算法の有奻性が分かる。

\section{3.まとめ}

音場の視覚化や可聴化による音場評価に用いるための基盤データとな
る可聴帯域の全周波数情報を含み、かつ残響部分までの長時間のインパ ルス応答を計算するために開発した計算手法、並びに実測值との比較に よりその有协性について述へてきた。今後は更にたくさんの物件によ る実則値との物理データの検証と同時に, 音場の視聴覚化による感覚的 な類似性についても検証していきたい。

\section{参考文献}

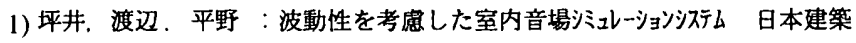
学会技術報告集、第 2 号。pp. $121 \sim 126.1996$ 年 3 月

2) T.Terai and Y.Kawai : The application of Kircchoff's formula to the numerical calculation of transient response in an enclosure, J. Acoust. Soc. Jpn(E) vol.11, no.1, pp.1-10, 1990

3) Y.Sakurai : The early reflection of the impulse response in an auditorium, $\mathbf{J}$. Acoust. Soc. Jpn(E) vol.8, no.4, pp.127-138, 1987

4) K.Sekiguchi, S.Kimura and T.Sugiyama : Approximation of impulse response through computer simulation based on finite sound ray intergrarion, J. Acoust. Soc. Jpn(E) vol.6, pp.103-115

5) 忠平好生：境界積分方程式法による過渡音場の解析手法について 日本音 酎学会誌 51 巻 3 号 1995 年

（1997年 2 月 10 日原稿受理，1997年 8 月 20 日採用決定） 